\title{
Expatriates' salary expectations, age, experience and country image
}

Article

Accepted Version

Duarte, H., de Eccher, U. and Brewster, C. (2021) Expatriates' salary expectations, age, experience and country image.

Personnel Review, 50 (2). pp. 731-750. ISSN 0048-3486 doi: https://doi.org/10.1108/PR-05-2019-0229 Available at https://centaur.reading.ac.uk/91378/

It is advisable to refer to the publisher's version if you intend to cite from the work. See Guidance on citing.

To link to this article DOI: http://dx.doi.org/10.1108/PR-05-2019-0229

Publisher: Emerald

All outputs in CentAUR are protected by Intellectual Property Rights law, including copyright law. Copyright and IPR is retained by the creators or other copyright holders. Terms and conditions for use of this material are defined in the End User Agreement.

\section{www.reading.ac.uk/centaur}

\section{CentAUR}

Central Archive at the University of Reading

Reading's research outputs online 
Expatriates' salary expectations, age, experience and country image.

Henrique Duarte (corresponding author)

ORCID: 0000-0002-0566-8793

BRU-IUL, University/Institution: Instituto Universitário de Lisboa (ISCTE-IUL), Portugal ISCTE- IUL Cacifo 175; Av das Forças Armadas,

1649-026 Lisboa -Portugal

E-Mail hmcd@iscte-iul.pt

Umberto de Eccher

ORCID: 0000-0002-5491-839X

BRU-IUL, University/Institution: Instituto Universitário de Lisboa (ISCTE-IUL), Portugal

E-Mail: $\underline{\text { u.deeccher@rde.it }}$

Chris Brewster

ORCID: 0000-0001-5314-1518

Henley Business School, University/Institution: University of Reading

E-Mail: c.j.brewster@henley.ac.uk

\section{There are no conflicts of interests}

This research did not receive any specific grant from funding agencies in the public, commercial, or non-for-profit sectors. 


\title{
Expatriates' salary expectations, age, experience and country image.
}

\begin{abstract}
Purpose: This paper explains how candidates' expectations of salary in relation to job offers as expatriates in developing societies are related to country image and to age.

Methodology: Data was collected from over 500 engineers living in France, Portugal, and Spain, evaluating two hypothetical expatriate proposals to six different African and Latin American countries. Multivariate hierarchical regression was applied to statistically detect significant predictors, with a broad range of control variables, to investigate expatriate salary expectations.
\end{abstract}

Findings: Results evidence the role of age, seniority, previous international experience and culture attraction for the host country in influencing salary expectations for potential expatriate postings. These results are discussed at the light of selection, optimisation and compensation theory (SOC), conservation of resources theory (COR) and social identity theory.

Practical implications: Findings call for multinational companies to consider age, individual background, career attributes and location concerns when evaluating salary expectations involved in expatriation to developing countries

Originality: The study shows how individual expectations about required salaries for accepting expatriate job offers in developing countries (hardly addressed in the extant literature) result from the potential for professional development opportunities and the responsibility of the jobs being offered, the country image, and the age and motivation of the individuals. Furthermore, it integrates research through use of SOC and COR theories 
Keywords: expatriates; location considerations; salary expectations; compensation; country image; rewards. 


\section{Introduction}

Expatriate compensation can influence the ability of multinational companies (MNEs) to attract, motivate and retain valuable employees (Harvey, 1993; Tornikoski, 2011). From the individual perspective, pay can enhance people's willingness to relocate and accept new job offers (Dickmann, Doherty, Mills \& Brewster, 2008; Doherty, Dickmann \& Mills, 2011; Dickmann \& Watson, 2017; Konopaske \& Werner, 2005; Stahl, Miller \& Tung, 2002; Wagner \& Westaby, 2009) but may be more important to some people than others (Cable \& Judge, 1994; Chiang \& Birtch, 2005). Effective expatriate assignments are critical for multinational enterprises (MNEs), so it is important to design attractive careers that can correspond to development expectations and reduce uncertainty (McNulty \& Vance, 2017), and establishing appropriate rewards for their effort in accomplishing the assignment (Stahl, et al., 2002). Despite numerous attempts to develop taxonomies of motivating factors influencing foreign relocation decisions (Dickmann, 2012; Dickmann et al., 2008; Doherty et al., 2011; Hippler, 2009; Kim \& Froese 2012; Noe \& Barber 1993; Stahl et al. 2002) and to the associated financial packages (Warneke \& Schneider, 2011), little effort has been made to uncover the predictors of international salary expectations (though see Bonache, 2006; Suutari \& Tornikoski, 2001; Bonache \& Zárraga-Oberty, 2017).

Studying candidates' expectations has practical and theoretical importance. Practically, it contributes to companies' ability to tailor their offers to possible applicants. Theoretically, it contributes to better understanding of how candidates present salary expectations in contexts of high uncertainty, such as assignments in developing countries. The conservation of resources (COR) theory (Halbesleben, Neveu, Paustian-Underdahl \& Westman, 2014; Hobfoll, 1989) and the selection, optimisation and compensation (SOC) theory (Baltes, 1997; Moghimi, Zacher, Scheibe \& Van Yperen, 2017), explain how individual variables might influence salary expectations taking into account age, past 
experience and motivation of applicants.

Individual expectations about future salaries are a key aspect of attracting workers with the necessary competences to fulfil MNEs needs. However, there is a trade-off between the importance of qualified candidates and the possible higher salary expectations they might have (Halbesleben, et al., 2014; Moghimi, et al. 2017). Career advancement could act as an intrinsic motivator reducing possible salary expectations (Dickman, et al., 2008). Researching the balance between the needs for conserving resources and the motivation for potential development is our first research issue. Expatriate salaries can be seen as a reward for past experience (Cable and Judge, 1994), as an employee's return for the contribution they make to their employers during their period abroad (Suutari, Tornikoski \& Mäkela, 2012), and as compensation for the perceived investments in the decision to relocate abroad (Bonache et al., 2009; Bonache \& Zárraga-Oberty, 2017). Candidates raise concerns about issues such as terrorism, safety and the political stability of the host country (Lowe, Downes \& Kroeck, 1999; Konopaske \& Werner, 2005; Scullion et al., 2007; Wagner \& Westaby, 2009; Bader \& Berg, 2014), which MNEs often attempt to alleviate by offering generous salaries (Bonache, 2006; Dickmann \& Watson, 2017; Wagner \& Westaby, 2009). So, two key questions emerge: to what extent do expectations about future salaries differ between destination countries? And, what justifications are presented for these variations?

In order to address the these issues, we analyse individual variables such as age, family, individual experience and motivations using COR and SOC theories to explain how they affect salary expectations (Halbesleben, et al, 2014; Moghimi et al. 2017). Specifically, to evaluate variation across destinations, we examine individuals' salary expectations for accepting hypothetical expatriate proposals in six developing countries, and explain possible differences using social-identity theory and stereotypical country images (De Eccher \& Duarte, 2018; Roth \& Diamantopoulos, 2009; Selmer \& Lauring, 2011). Unlike earlier studies 
on expatriate compensation that focused mainly on samples from the USA (Harvey, 1993; Konopaske \& Werner, 2005; Sims \& Schraeder, 2005; Wagner \& Westaby, 2009), this investigation included individuals living in three European countries (France, Spain, and Portugal). Finally, considering the lack of technical talent in developing countries (UNESCO, 2010) and the frequent use of technical personnel for expatriate assignments (Huang, Chi \& Lawler, 2005), the research focuses on the potential salary concerns of engineers.

The paper takes the following form: we examine the literature to identify a conceptual framework and relevant hypotheses (see Figure 1). Then, we introduce our methodology. Results show that salary expectations correspond to SOC and COR predictions, and that maintaining individual variables constant, salary expectations do vary between possible destinations. Finally, we discuss the findings, implications, and avenues for future research opened up by our work.

\section{Insert Figure 1 about here}

\section{Expatriate compensation in the literature}

\section{Individual antecedents of salary expectations}

A first explanation of salary expectations is taken from SOC theory (Baltes, 1997; Moghimi, et al, 2017): older employees are more selective about job offers, look to optimise available resources and pursue higher compensation. It's expected that, confronted with job offers in foreign countries, they will be less willing to move and demand higher salaries for the challenges they might face and the loss of job stability. Younger staff may be expected to focus on prospects for career advancement, travel and adventure (Selmer \& Lauring, 2011; von Bonsdorff, 2011); with lower salary expectations as a symptom of their greater willingness to move (Noe \& Barber, 1993; Eby \& Russell, 2000). Thus, we propose that: 
Hypothesis 1: Older individuals will have higher salary expectations for accepting expatriation than younger individuals.

Although seniority in a company might be correlated with age, it could also be correlated with mobility. Experience of international contexts differs widely between possible candidates for expatriation. Perceived job stability and the compensation effects depend not just on age but also on the evaluation individuals make about their own resources and motivations, which in turn is dependent on their past (Halbesleben, et al, 2014). COR theory (Halbesleben, et al, 2014; Hobfoll, 1989; Hobfoll, et al, 2018) suggests that resource gains increase in salience when possible loss of resources exists. This idea is consistent with previous findings that senior employees are less willing to accept new career opportunities and present higher demands for salary (eg. Cable and Judge, 1994). Thus, employees with higher seniority might evaluate greater insecurity and higher probability of losses in future expatriation offers. The probability of losses could be expected to lead to higher compensation expectations when compared with less senior workers who would be less likely to be engage in such defensive strategies. So:

Hypothesis 2: Individuals with higher seniority in a company will have higher salary expectations for accepting expatriation than individuals with less seniority. Conversely, the expatriate literature highlights the fact that individuals' previous international experience positively influences their willingness to move abroad (Dickmann et al., 2008; Doherty et al., 2011; van der Velde, Bossink \& Jansen, 2005) and their better adaptation to expatriate assignments (Jenkins \& Mockaitis, 2010; Lee \& Sukoco, 2010; Shim \& Paprock, 2002; Takeuchi, Tesluk, Yun \& Lepak, 2005). People with foreign experience are more likely to enjoy cultural diversity (Suutari et al., 2012), to have realistic expectations, to have higher tolerance for ambiguity, and to have greater cultural intelligence (Dewaele \& Wei, 2013; Lee \& Sukoco, 2010; Tharenou, 2008) and greater cross-cultural competencies 
(Tarique \& Weisbord, 2013). COR theory (Halbesleben, et al, 2014; Hobfoll, 1989; Hobfoll, et al, 2018) suggests that when resources are stretched or exhausted individuals are more likely to enter into a defensive mode, although less so in the case of resourceful individuals. It might be expected that it would make a difference whether the previous experience was happy or unhappy (Sanchez-Vidal, Sanz Valle \& Barba Aragón, 2008) but it seems that, with the passing of time, most expatriates value their previous experience ( Suutari, Brewster, Dickmann, Mäkelä, Tanskenan \& Tornikoski, 2018) and the evidence cited above is that it is the experience itself that matters. We can expect that individuals with more international experience will consider themselves more resourceful, feel better able to face uncertainty and thus will have less demanding requirements when compared with individuals with lower international experience. Thus:

Hypothesis 3: Individuals with greater international work experience will have lower salary expectations for accepting expatriation than individuals with less international work experience.

\section{Motivational antecedents of salary expectations}

Among the multiplicity of issues motivating international relocation, career-related aspects are often ranked as the most important drivers (Dickmann 2012; Dickmann et al., 2008; Doherty et al., 2011; Oberholster, Clarke, Bendixen \& Dastoor, 2013; Stahl et al., 2002), although there is an inevitable interaction between personal attributes, motivation and reward preferences (Cable \& Judge, 1994; Chiang \& Birtch, 2005; Suutari \& Brewster, 2000; von Bonsdorff, 2011). Variables that have been identified as predictors of salary expectations include personal challenge (Pinto, Cabral-Cardoso \& Werther, 2012; Stahl et al., 2002), current employment situation (Doherty et al., 2011; Suutari \& Brewster, 2000), family (Konopaske et al., 2009; Selmer \& Lauring, 2011), and financial aspects (Dickmann et al, 
2008; Stahl et al., 2002). However, theoretical integration is missing, and we argue that these findings can be integrated into the COR theory framework.

First, individuals dissatisfied with their current professional situation will evaluate fewer losses from possible mobility decisions. When the salience of loss is lower, or a professional opportunity brings intrinsic career gains we might expect that the need for compensating gains from salaries would also be lower. Also, when an expatriate decision is related to a personal challenge, candidates might be more interested in the personal nonfinancial gains (Hipler, 2009; Dickmann, et al, 2008), paying less attention to possible losses; and thus be less demanding in terms of salary expectations. So we propose:

Hypothesis 4a: An unsatisfactory current employment situation will be negatively associated with salary expectations for accepting expatriate offers.

Hypothesis 4b: Personal challenge in relocation decisions are negatively associated with salary expectations for accepting expatriate offers.

Hypothesis 4c: Professional opportunity in relocation decisions are negatively associated with salary expectations for accepting expatriate offers.

On the other hand, for people with a family, possible losses may be more salient due to the risks that family members could confront. COR theory (Halbesleben, et al, 2014; Hobfoll, 1989) leads us to predict that, if potential losses accrue not only to the individual but also to the family, salary expectations would be higher. In the same vein individuals motivated by extrinsic aspects, like financial gains, as may occur with workers in older career stages (Duarte \& Lopes, 2018) can be more demanding in their salary expectations (Stahl, et al., 2002; Dickman, et al., 2008). Moreover, more financial resources might give them more opportunities for family and/or social activities (Dickmann \& Watson, 2017). Taking these rationales into account we propose the following hypotheses: 
Hypothesis 4d: Where families are concerned in relocation decisions, this is positively associated with salary expectations for accepting expatriate offers. Hypothesis 4e: Financial concerns in relocation decisions are positively associated with salary expectations for accepting expatriate offers.

\section{Country image and language skills as antecedents of salary expectations}

While individual characteristics and motivational aspects can answer our research questions about the level of expected rewards in broad way, they do not fully explain why there are differences between salary expectations for different country destinations. Possible explanations can be derived from identification with host countries. Theories of intergroup bias, such as social identity theory (Tajfel, 1972) and self-categorisation theory (Turner, 1985), suggest that subjective uncertainty can lead people to identify with similar people (i.e. an in-group), and to make use of symbolic inference like stereotypical country images to accentuate differences with dissimilar groups (i.e. an out-group) (Caligiuri, Phillips, Lazarova, Tarique \& Bürgi, 2001; Hewstone, Rubin \& Willis, 2002; Hogg, 2000). Therefore, we anticipate that by reducing the creation of stereotypical evaluations, foreign experience reduces the aversion and concerns involved in moving abroad, consequently diminishing the pay expectations for accepting expatriate offers. Host language fluency, in particular, will assist expatriate adjustment (Jenkins \& Mockaitis, 2010; Selmer, 2006; Shim \& Paprock, 2002; Takeuchi, Yun \& Russell, 2002), reduce the creation of stereotypes (Caligiuri and colleagues, 2001), and provide a shared social identity leading to the emergence of in-group identification (Selmer \& Lauring, 2011). Thereby, language and the presence of communities from the same nationality, ethnicity, religion and culture can positively impact country image (Carr, Inkson \& Thorn, 2005). Therefore, host language fluency might reduce the demands of expatriates for high salaries. Thus, we expect the following: 
Hypothesis 5: Individuals considering moving to a country where their own language is spoken will have lower salary expectations for accepting expatriation than those of individuals whose home countries have a different language.

Following the above rational individuals' host country image may influence salary expectations. Organisational culture, both in the home and host country, are important predictors of retention and reduction of withdrawal intentions (Pinto, Cabral-Cardoso \& Werther, 2017). Expatriate remuneration helps to balance the cultural, social, psychological and economic variations generated by relocation, as well as maintaining, or improving upon, current standards of living (Arp, Hutchings \& Smith, 2013; Bonache, 2006). Analysing quality of life cross-nationally, we can distinguish between more objective indicators such as the level of safety, political stability, quality of healthcare and infrastructure (Diener \& Suh, 1997; Schalock, Verdugo, Jenaro, Wang, Whemeyer, Jiancheng \& Lachapelle, 2005), and more subjective dimensions such as the cultural and relational-level variables, which contribute to the well-being of individuals (Cummins, Eckersley, Pallant, van Vugt \& Misajon, 2003; Dickmann \& Watson, 2017). Cultural and relational aspects interact with the socio-economic and political dimensions of location. For instance, a perceived safety risk provoked by terrorism lowers the willingness of expatriates to interact with host country citizens (Bader \& Berg, 2013), though Lowe and colleagues (1999) point out that access to adequate infrastructure can to some extent offset concerns related to cultural distance and political risk. We can expect a higher degree of uncertainty involved in the evaluation of possible expatriate destinations in less developed countries. In line with social identity theory, the uncertainty deriving from ambiguous information about the destination, combined with the consequent use of stereotypes to create expectations, may lead individuals' to infer a negative country image in such cases (Alniaçik, Erat \& Akçin, 2014; Baum \& Kabst, 2013, 
Caligiuri et al., 2001). Therefore, considering their higher subjective susceptibility, we expect country image variables to influence salary expectations:

Hypothesis 6: $\quad$ More negative evaluation of country characteristics will influence higher salary expectations.

Finally, the effects of country image may differ depending on individual characteristics. Negative country image could affect the different valuation of information, and the strategies that expatriates can adopt to surpass these negative evaluations, so depending on the individual, may not necessarily need to be compensated by an increase of salary. SOC theory (Baltes, 1997; Moghimi, et al., 2017) suggests that older employees tend to be more selective about the situations that might affect them in the future (Baltes, et al, 2014) and will scrutinise more information about possible job offers and, in the expatriation context, more information about possible locations. Thus, we expect an interaction between the image of countries and the age of employees. More specifically we expect that older employees give weight to the images they create about possible destinations, while younger workers tend not to do so. Greater scrutiny could lead to a stronger valuation of the negative aspects, such as health facilities, by older workers, who will therefore ask higher salaries, while this information may not be so valued by younger workers. Further, the negative evaluation of socio-economic aspects might be devalued by younger workers since they may be more focused on intrinsic aspects of career advancement (Duarte \& Lopes, 2018; Selmer \& Lauring, 2011; von Bonsdorf, 2011). Considering previous arguments, we expect that the differential of salary expectations between more positive images and negative images of countries will be higher for older workers when compared with younger ones, so:

Hypothesis 7: The negative effect of country image characteristics is moderated by the age of individuals, leading to a higher differential of salary expectations 
between more positive and negative images for older employees when compared with younger ones.

\section{Methodology}

\section{Design and data analysis}

To test our hypotheses, we used a cross-sectional study with a within-subjects design. To understand how expatriates formulate salary expectations, we presented two job offers (A and B) in six countries. To each of the scenarios, respondents evaluated the image they have of each country (De Eccher \& Duarte, 2018), and assessed motivations to accept international assignments (Dickmann, et al., 2008), and their salary expectations for each pair of job offers in the six countries. Finally, we collected individual variables related with the main predictions of SOC and COR theories: age, seniority and years of international experience, language (Carr et al. 2005) and, as control variables, we checked gender, marital status, children and type of contract (De Eccher \& Duarte, 2018; Ho et al, 2016; Noe \& Barber, 1993; Schweitzer et al., 2014). The comparative analysis took into account the different salary expectations, and the individual and motivational variables and country image evaluations.

Specifically we confronted participants living in France, Spain and Portugal with scenarios of possible locations to two job offers (Job A and B) in six countries: (two Frenchspeaking - Algeria, Democratic Republic of the Congo (DRC); two Portuguese-speaking Angola, Mozambique; and two Spanish-speaking - Argentina, Chile). Multivariate hierarchical regression was applied to detect statistically significant predictors of salary expectations.

Two hypothetical job positions were offered (i.e. Job offer A = Lead Engineer, and Job offer B = Project Manager). In line with earlier expatriate studies (Lowe et al., 1999; Wagner \& Westaby, 2009), scenarios were presented by means of a 'realistic' narrative 
proposal summarising the project's context, job responsibilities, and the main expatriate benefits provided by the fictitious multinational employer. For each of the job positions we presented a package of benefits, namely: housing, car, food allowance, health and life insurance, and round-trips to the home country. In turn, respondents were asked to report their degree of willingness and minimum base net salary required for them to accept such a proposal in each of the six countries. We also asked about their salary expectations if they accepted those positions in their own home-country (without any benefits involved), in order to have an idea of the average differentials to more risky countries when compared with their own. Descriptive statistics of these expectations are reported on Table 1.

Briefly, the job description of the 'Lead Engineer' stated responsibilities over $10 \%$ of an on-going $€ 5,000,000$ project, and the supervision of a local technical team of two employees and communication with relevant stakeholders; the job description of the 'Project Manager' stated planning, launching and managing the implementation of a prestigious institutional project valued at $€ 50,000,000$, coordination of a unit with 80 employees and full responsibility over the financial, commercial, technical and managerial aspects. By examining the salary expectations for these two job offers we aimed to capture the different impacts that the same individual variables could have on possible mobility decisions.

To evaluate the extent to which expectations about future salaries differ between destination countries, we analysed differences using an ANOVA between the expectations for host country and each of the destination countries (Table 1). Then we used a two-step approach on the linear regressions to evaluate to what extent the country image characteristics and the proposed interactions might explain the differences between countries (table 2 and 3 ). To compare the magnitude of effects we used standardised betas. For these analyses we have a trial question asking for the willingness to accept the job offer in the suggested destination. As a filter, we didn't consider salary expectations to countries where people stated they were 
not willing to go.

\section{Variables}

For the dependent variables (salary expectations), participants were asked to input a numerical value corresponding to the requested net yearly basic salary (in Euros). The aim was to reduce problems arising from cross-national differences in pay systems which may have caused the salary data collected to be unreliable. The study focused on three areas of antecedents of salary expectations: individual variables that can test the predictions of SOC and COR and some control variables; a second group to evaluate if usual motivations to accept international assignments influence salary expectations; a third group of variables used to evaluate several dimensions of expatriates build country images.

On the first group of variables, respondents' demographics were assessed through the use of dummy and continuous variables. First, we checked age (years), gender $(0=$ female, 1 $=$ male); marital status (recoded as $0=$ single, widowed, divorced, separated, and $1=$ married or with domestic partner $)$; and children under 13 years old $(0=$ no children, $1=$ have children). Another set of variables measured the professional situation and experience of participants through questions addressing years of international experience, seniority in the company (years), and work status (dummy variable, $1=$ employed full-time, and $0=$ other).

The motives that could influence the acceptance of the job offers were related to the employment situation, career opportunities, personal challenge, family and financial aspects, measured and adapted into a 5-point scale utilising the items employed by Dickmann and colleagues (2008). For each of the above motives, we used just one question repeated for Job Offer A and Job Offer B). Specifically we asked "to what extent does each factor influence your decision to expatriate as ..." and answers ranged from "no influence" to "very great influence" and were used to quantify the motivational power of five items: 1) current 
professional dissatisfaction, risk and lack of opportunities; 2) professional opportunity for development and achievement; 3) personal challenge and enjoyment of international experience; 4) family considerations and responsibilities; and 5) financial considerations. Country image was measured on six main items (De Eccher \& Duarte, 2018). These six items were evaluated individually but they correspond to two main dimensions: the socioeconomic-political and the cultural-relational. The first dimension was assessed through questions using perceived quality of life indicators such as levels of safety ( $1=$ very unsafe to $5=$ very safe $)$, quality of healthcare and infrastructures $(1=$ very poor to $5=$ very good $)$ and political stability ( $1=$ very unstable to $5=$ very stable $)$. The second dimension was assessed through questions related to the respondents' level of culture attraction to the country $(1=$ "not at all attracted" to 5= "very attracted"), and degree of openness of host country nationals towards foreigners ( $1=$ "not at all open to foreigners" to $5=$ "very open to foreigners").

\section{Data collection and study sample}

Our convenience sample used LinkedIn to filter and address engineers with different demographic and professional backgrounds. We addressed customised messages explaining the study by means of online questionnaires in English sent to individuals holding engineering-related undergraduate degrees, focusing on French, Portuguese and Spanish nationals.

We sent out 908 questionnaires and received 515 usable answers: a response rate of $68.5 \%$. Given that not all participants communicated the salary requests for all countries and job offers, particularly for those nations in which they were unwilling to accept expatriation under any conditions, a total of 3150 observations of salary expectations were received. After removing the missing values and people not willing to accept job offers, we had 2741 observations for Job A and 2704 for Job B in the different countries (Table 1): Algeria (449 
Job A; 443 Job B), Angola (455; 451), Argentina (469; 463), Chile (470; 462), DRC (436;

432), and Mozambique (455; 453). The filtered observations correspond to data retrieved from a total of 470 respondents (France -112; Portugal - 118; Spain - 117; other nationalities - 123). Approximately $14 \%$ of observed salary expectations were from women, matching the gender ratio present in university engineering degrees (Cronin \& Roger 1999), and indicating the representativeness of our survey. In addition, most expected salary observations derived from individuals in their thirties $(M=35.2, S D=8.5)$, who were married or living with a partner (55\%), with civil engineering university degrees (56\%), not having children younger than 13 years old (64\%), being currently employed full-time (67\%) - rather than as freelancers, or part-timers - with more than five years working in the same company (25\%), and who had lived abroad for more than one year (58\%).

\section{Findings}

\section{Differences in Salary Expectations}

To evaluate differences between net yearly salary expectations between the destination countries, and their magnitudes (see Table 1), we conducted ANOVAs and post-hoc Tukey tests. Expected salaries for Job A evidence significant differences between countries $(\mathrm{F}=9.766, p<.00)$, as well as differentials in comparison with the expected value for a similar job in the home country $(\mathrm{F}=22.204, p<.00)^{1}$. Post hoc tests evidence three groups, where expectations for Chile and Argentina (79,944 euros; 80,696 euros) were lower than those for Algeria (93,952 euros) and higher than for Mozambique, Angola and DRC (96,343 euros; 98,827 euros; 106,024 euros). Similarly, job B showed lower expectations for Chile and Argentina (111,121 euros; 112,462 euros) than Algeria and Mozambique (129,478 euros;

\footnotetext{
${ }^{1}$ Differentials are calculated using the average of the individual differentials in the sample with the formula: "(salary expectation to Job A in host country - salary expectation to job A in home country) / salary expectation to job A in home country".
} 
131,346 euros), with higher expectations for Angola and DRC (134,047 euros; 144,355 euros).

\section{Insert Table 1 about here}

The differentials vary on average between $35.1 \%$ and $36.1 \%$ for Chile and Argentina, 55.3\% and 59.4\% for Algeria and Mozambique and between $62.8 \%$ and 78.0\% for Angola and Congo. However, when we compare the differences in the differentials of expectations between Job B and Job A, they are non-significant $(\mathrm{F}=.122, p=.988)$, varying between $40.7 \%$ and $45.0 \%$. These results provide evidence that when people are confronted with different destinations they do indeed discriminate in favour of some countries and against others and might use salaries to compensate for the evaluations they make. However, the differentials between the proposed two job offers are relatively similar, around $40 \%$, and do not vary between destinations.

\section{International Salary Expectations predictors}

Tables 2 and table 3 show the results of the regression models for net yearly salary expectation for accepting job offers A and B in the home country and the six host countries. We used regression analysis in two steps. In the first we evaluated the contribution of individual variables and in the second we introduced the country variables and the possible interactions with age to test hypothesis 7 . Analysis of the explained variance shows that the individual variables included in the models, F-values, are statistically significant in all the models $(p<.01)$, and the adjusted $\mathrm{R}^{2}$ reported in the results varies from .09 to .14 for the regressions free of location variables, and rises to .06 when loading the country dimensions, thereby highlighting that individual variables are more robust in explaining variations in the international salary expectations than the location variables included in the model, even 
though location variables do explain differences in almost all the scenarios (exception for Job A and Job B in DRC and Job B in Chile).

\section{Insert Table 2, Table 3 and Figure 2 about here}

Looking more closely at the standardized $\beta$ of the individual predictors, first, age presents higher values and positively related salary expectations in all countries for the two job offers, allowing us to accept Hypothesis 1.

Second, as expected, seniority is also positively related to salary expectations (with the exception of Job A in Algeria and Argentina), so we accept Hypothesis 2. Nevertheless, seniority presents higher coefficients on the models for Job B than Job A, which could mean that more people, when confronted with jobs with higher responsibilities, expect higher compensation for the greater risk than is the case with less demanding jobs. Similarly, possible candidates with full time contracts expect higher salaries in some of the scenarios (Job A and B in Algeria and DRC).

Third, the effects of previous international experience show mixed results. While, as predicted by Hypothesis 3, greater international experience is associated with lower salary expectations for Job B, for Job A this was not the case, giving only partial support to this hypothesis.

Fourth, from the different personal motives that might affect salary expectations, only feeling that the actual situation is unsatisfactory is related to salary expectations (exceptions are Job A and B in Mozambique and Job B in Angola), leading us to accept Hypothesis 4a, but reject Hypotheses 4b, 4c, 4d and 4e.

Further, the results here for Job A are more robust than for Job B. This aspect, in conjunction with the findings for international experience, suggest dissatisfaction can indeed lead to pressure for a job with less responsibilities, with people preferring to move and 
therefore not being so demanding with the salaries they require. However, when jobs are more demanding, past experience plays a part in evaluating risks and possible compensations.

Fifth, despite our expectation that individuals having the same language as the destination country would feel more familiar with it and therefore evidence lower salary expectations, the data show no significant effects. So we reject Hypothesis 5.

\section{Country image and salary expectations}

Sixth, given the strong differences of salary expectations (table 1), we expected that this would be explained by country variables. Although contributing to some extent, and in the predicted direction, the added variance explains only a further .01 to .06. Culture attraction presents direct effects or possible interactions in almost all of the models (exceptions are Job A and B in DRC and Job B in Chile) and the evaluation of infrastructures also shows some effects on salary expectations (Job A in Angola and Mozambique; Job B in Algeria, Angola, Argentina, DRC and Mozambique). As predicted, a better evaluation of these dimensions is associated with a lower salary expectation, so we partially accept Hypothesis 6.

Finally, in some of the models these two dimensions show main effects, and interaction effects are also detected (Job A and B in Algeria, Angola, Argentina and Mozambique). In Figure 2 we present the interaction effects and show two principle antecedents: higher age is always associated with higher salary expectations; and a better evaluation of the country is associated with lower salary expectations. The interactions present the expected pattern, with older individuals showing a strong differential between low and high evaluations of country dimensions, and younger candidates not being so sensitive. So, on these findings, we partially accept Hypothesis 7.

\section{Discussion: antecedents of expatriate compensation expectations}

Our first strong evidential finding concerns the differences that people show in terms of salary 
expectations between proposed destinations. Using a scenario within-subjects study and maintaining individual variables as constant, salary expectations clearly vary between possible destinations. The characteristics of the countries influence compensation demands.

A first explanation of these differences supports selection, optimisation and compensation theory (Baltes, 1997; Moghimi, et al, 2017). First, our findings show that older individuals have higher salary expectations (Hypothesis 1 was confirmed) and evaluate the characteristics of the countries differently. In some situations, older individuals show more sensitivity to some characteristics (culture attraction, infrastructures) to which younger individuals are almost indifferent (hypothesis 7 was partially confirmed). More selective behaviours of older workers or their greater need to compensate future challenges could be an explanation. The results clarify the outcome of previous studies that didn't use this framework (Eby \& Russell, 2000; Noe \& Barber, 1993; Selmer and Lauring, 2011, von Bonsdorff, 2011). Our findings contribute also to SOC theory, since they tend to concentrate the compensation effects onto a reduction of satisfaction, effort and performance. It seems reward policies might motivate older employees who are more sensitive to extrinsic rewards (Duarte \& Lopes, 2018).

A second explanation of our finding is sustained by conservation of resources theory (Halbesleben, et al, 2014; Hobfoll, 1989; Hobfoll, et al, 2018). Our results indicate that employees with more seniority and, in some situations, the ones that have full employment contracts, have higher salary expectations (Hypothesis 2). They want to preserve the stability of their jobs and to be compensated to leave it for another. Senior employees have a lower propensity to accept new career opportunities; and a higher propensity to demand better salaries (Cable \& Judge, 1994). We tested whether respondents tend to devalue salaries when they have an unsatisfactory situation (Hypothesis 4a) or when they sought a personal challenge (Hypothesis 4b) or a professional opportunity (Hypothesis 4c). But whilst defensive 
strategies exist when individuals feel their situation as satisfactory, the opposite didn't occur. Even for a professional opportunity or a personal challenge, they do not devalue the salary increase associated with new job offers. This contrasts with the propositions that people's intrinsic motivations, such as career opportunities, can to some degree compensate their need for extrinsic incentives (Bonache et al., 2009; Shaffer et al., 2012).

Location also influences individuals' salary expectations for accepting expatriate positions in developing countries. Our results show that the more favourable the respondents' evaluation of the cultural aspects of the host country (item cultural attraction), the lower the salary that would expected for accepting a job offer there (Hypothesis 6), agreeing with Wagner and Westaby (2009). Such results fit with social identification theory; but also fit with COR theory - if people evaluate host countries' cultures in a negative way, they expect negative social exchanges in relocation decisions and use salary requests to balance the difficulties they forecast. Countries' socio-economic and political dimensions play a part in this (item infrastructures), in accordance with findings on relocation willingness and adjustment (Lowe et al., 1999; Wagner \& Westaby, 2009; Kim \& Froese, 2012). Doherty and colleagues (2011) found similar things, emphasising the influence of the expected interface with locals on salary expectations.

\section{Limitations}

Our investigation is limited, first, by the sample: the participants were civil engineers and, reflecting that population generally, not enough of the respondents were female to allow us to check whether their responses were different. There are indications in the previous literature that they might be (Shah \& Monahan, 2018; Stoermer, Davies, Bahrisch \& Portniagin,2017) and this is an area for further research in a less male-dominated sector.

Second, we did not ask whether the respondents had any experience of the sample 
countries, thus limiting our information about their knowledge of each potential destination. It seems unlikely that any respondents would have had experience of more than one or two of these destinations and most will have had none, so we were able to meet our intention of capturing the individual location perceptions of non-experts on the countries and comparing that with expected salary variations. Nor did we control their current positions, and whether the two job offers were an upgrade on their existing one, although we assured a baseline comparison by asking for the expected values in their own country. Finally, the job proposals involved long-term expatriate offers and Konopaske and colleagues (2009) suggest salary expectations might decrease if participants were asked to relocate for a shorter period. For the sake of parsimony (participants had to make twelve proposals for salaries: two job offers x six countries), we used single items to measure the different motivations and country image dimensions, which might also limit the reliability of the findings. Future research could build on our findings and focus on the type of motivations and the more significant country dimensions using more complex measures.

\section{Implications and future research}

We examined multiple antecedents of salary expectations for expatriate job postings. The practical implications of our findings are that MNEs would do well to pay attention to the professional situation and career motives of individuals considering moving abroad. It will be easier to persuade intrinsically motivated employees to go abroad (Bonache et al., 2009) and to retain them. There remains considerable room for further investigation regarding the interaction between salary preferences and relocation motives in the cross-national context and we welcome similar studies in other professions and for other countries.

As expected, the study shows that the greater the responsibility and the higher the position involved in the international job proposal, the higher the base salary expected for accepting it. However, it is important to note that within this general statement, salary 
demands differ significantly for the different destinations (table 1). The characteristics of the countries used in this study, although they predicted willingness to move (De Eccher \& Duarte, 2018), were not so robust in explaining salary differences (table 2 and 3), perhaps because we excluded those who would not go. The inclusion of more variables linked with economic aspects of the country might bring new perspectives to the possible salary differences. We also encourage further research on expatriate salaries from the 'other' perspective, that of the locals (Oltra, Bonache \& Brewster, 2013; Toh \& DeNisi, 2003). The use of more complex measures on motivations, possible self-efficacy and career perspectives could enrich the analysis. We also consider that nuances related with the quality of past experience exist (Suutari, Brewster, Dickmann, Mäkelä, Tankenan \& Torniskoksi (2018), and it would be interesting to evaluate how they might influence salary expectations.

From the existing findings, selection policies must balance the ease of recruiting older, more senior employees with previous international experience with the salary expectations that such candidates will present. Older workers can be retained when companies assure a fair salary and maintain annual pay raises (Gevrek et al, 2017), thus dissuading the acceptance of other offers. On the other hand, the importance of impressions of host country nationals in explaining salary expectations draws attention to the need for MNEs to emphasise the interface between expatriate employees and locals (Hechanova, Beehr \& Christiansen, 2003; Toh \& DeNisi, 2007). MNEs could also provide and promote information about the host country culture, and its infrastructure, in order to reduce individuals' stereotyped perceptions of destination countries, allowing individuals to have more realistic job previews and more accurate salary expectations. Future expatriate research could help to identify and interpret further country dimensions that influence international salary expectations. 


\section{References}

Alniaçik, E., Alniaçiç, Ü. Erat, S. and Akçin, K. (2014), “Attracting talented employees to the company: Do we need different employer branding strategies in different cultures?", Procedia - Social and Behavioral Sciences, Vol. 150, pp. 336-344

Arp, F., Hutchings, K. and Smith, W.A. (2013), "Foreign Executives in Local Organizations: An Exploration of Differences to Other Types of Expatriates", Journal of Global Mobility, Vol. 1, No. 3, pp. 312-335.

Bader, B. and Berg, N. (2014), "The influence of terrorism on expatriate performance: a conceptual approach", International Journal of Human Resource Management, Vol. 25, No. 4, pp. 539-557.

Baltes, P. (1997), "On the incomplete architecture of human ontogeny: Selection, optimization, and compensation as Foundation of developmental theory", American Psychologist, Vol. 52, No. 4, pp. 366-380.

Baltes, B., Wyne, K., Sirabian, M., Krenn, D. and de Lange, A. (2014), "Future time perspective, regulatory focus, and selection, optimization, and compensation: Testing a longitudinal model”, Journal of Organizational Behavior, Vol. 35, pp. 1120-1133.

Baum M. and Kabst, R. (2013), "How to attract applicants in the Atlantic versus the Asia-Pacific region? A cross-national analysis on China, India, Germany, and Hungary", Journal of World Business, Vol. 48, pp. 175-185.

Bonache, J. (2006), "The compensation of expatriates: a review and a future research agenda", in Stahl, G.K., and Björkman, I., Cheltenham (Eds.), Handbook of Research in International Human Resource Management, UK: Edward Elgar, pp.158-175.

Bonache, J. and Zaágarra-Oberty, C. (2017), "The traditional approach to compensating global mobility”, International Journal of Human Resource Management, Vol. 28, No. 1, pp. 149-169.

Bonache, J., Sanchez, J. and Zárraga-Oberty, C. (2009), "The interaction of expatriate pay differentials and expatriate inputs on host country nationals' pay unfairness", International Journal of Human Resource Management, Vol. 20, No. 10, pp. 21352149.

Cable, D.M. and Judge, T.A. (1994), "Pay preferences and job search decisions: a personorganization fit perspective", Personnel Psychology, Vol. 47, pp. 317-348.

Caligiuri, P.M., Phillips, J., Lazarova, M., Tarique, I. and Bürgi, P. (2001), "The theory of met expectations applied to expatriate adjustment: the role of cross-cultural training", International Journal of Human Resource Management, Vol. 12, No. 3, pp. 357-372. 
Carr, S.C., Inkson, K. and Thorn, K. (2005), "From global careers to talent flow: reinterpreting 'brain drain'”, Journal of World Business, Vol. 40, pp. 386-398.

Chiang, F.F.T. and Birtch, T.A. (2005), “A taxonomy of reward preference: examining country differences", Journal of International Management, Vol. 11, pp. 357-375.

Cummins, R.A., Eckersley, R., Pallant, J., van Vugt, J. and Misajon, R. (2003), “developing a national index of subjective well-being: the Australian Unity well-being index", Social Indicators Research, Vol. 64, pp. 159-190.

Cronin, C, and Roger, A. (1999), “Theorizing progress: women in science, engineering, and technology in higher education", Journal of Research in Science Teaching, Vol. 36, pp. 637-661.

Dewaele, J.M. and Wei, L. (2013), "Is multilingualism linked to a higher tolerance to ambiguity?", Bilingualism: Language and Cognition, Vol. 16, No. 1, pp. 231-240.

Dickmann, M., Doherty, N., Mills, T. and Brewster, C. (2008), "Why do they go? individual and corporate perspectives on the factors influencing the decision to accept an international assignment", International Journal of Human Resource Management, Vol. 19, No. 4, pp. 731-751.

Dickmann, M. (2012), "Why do they come to London?: Exploring the motivations of expatriates to work in the British capital ", Journal of Management Development, Vol. 31, No. 8 , pp. $783-800$.

Dickmann, M. and Watson, H. (2017), “'I might be shot at!” exploring the drivers to work in hostile environments using an intelligent careers perspective",, Journal of Global Mobility, Vol. 5, No. 4, pp. 348-373,.

Diener, E. and Suh, E. (1997), "Measuring quality of life: economic, social and subjective indicators", Social Indicators Research, Vol. 40, pp. 189-216.

Doherty, N., Dickmann, M. and Mills, T. (2011), "Exploring the motives of company-backed and self-initiated expatriates", International Journal of Human Resource Management, Vol. 22, No. 3, pp. 595-611.

Duarte, H. and Lopes, D. (2018), "Career stages and occupations impacts on workers motivations”, International Journal of Manpower, Vol. 39, No. 5, pp. 746-763.

De Eccher, U. and Duarte, H. (2018), "How images about emerging economies influence the willingness to accept expatriate assignments", International Journal of Human Resource Management. Vol. 29, No. 4, pp. 637-663.

Eby, L.T. and Russell, J.E.A. (2000), "Predictors of Employee Willingness to Relocate for the Firm”, Journal of Vocational Behavior, Vol. 57, pp. 42-61. 
Gevrek, D., Spencer, M., Hudgins, D. and Chambers, V. (2017), "I can't get no satisfaction: The power of perceived differences in employee intended retention and turnover", Personnel Review, Vol. 46, No. 5, pp. 1019-1043.

Haines, V. III, Saba, T. and Choquette, E. (2008), "Intrinsic motivation for an international assignment”, International Journal of Manpower, Vol. 29, No. 5, pp. 442-461.

Halbesleben J., Neveu J., Paustian-Underdahl S. and Westman M. (2014), "Getting to the 'COR': understanding the role of resources in conservation of resources theory", Journal of Management, Vol. 40, No. 5, pp. 1334-1364.

Harvey, M. (1993), "Designing a global compensation system: the logic and a model", The Columbia Journal of World Business, Vol. 28, No. 4, pp. 56-72.

Hechanova, R., Beehr, T. and Christiansen, N. (2003), "Antecedents and consequences of employees' adjustment to overseas assignment: a meta-analytic review”, Applied Psychology: An International Review, Vol. 53, No. 2, pp. 213-236.

Hippler, T. (2009), "Why do they go? Empirical evidence of employees' motives for seeking or accepting relocation", International Journal of Human Resource Management, Vol. 20, No. 6, pp. 1381-1401.

Ho, N. T. T., Seet, P. S., \& Jones, J. (2016). “Understanding re-expatriation intentions among overseas returnees-an emerging economy perspective". International Journal of Human Resource Management, 27(17), 1938-1966.

Hobfoll S. (1989), "Conservation of resources: a new attempt at conceptualizing stress", American Psychologist, Vol. 44, No. 3, pp. 513-524

Hobfoll, S, Halbesleben, J., Neveu, J. and Westman, M. (2018), "Conservation of resources in the organizational context: The reality of resources and their consequences", Annual Review of Organizational Psychology and Organizational Behavior, Vol. 5, pp. 103128

Huang, T.S., Chi, S.C. and Lawler, J.J. (2005), "The relationship between expatriates personality traits and their adjustment to international assignments", International Journal of Human Resource Management, Vol. 16, No. 9, pp. 1656-1670.

Jenkins, E.M. and Mockaitis, A.I. (2010), "You are from where? the influence of distance factors on New Zealand expatriates' cross-cultural adjustment", International Journal of Human Resource Management, Vol. 21, No. 15, pp. 2694-2715.

Jurgensen, C.E. (1978), “Job preferences: what makes a job good or bad?”, Journal of Applied Psychology, Vol. 63, No. 3, pp. 267-276.

Kim, J. and Froese, J. (2012), "Expatriation willingness in Asia: the importance of host-country characteristics and employees role commitments", International Journal of Human Resource Management, Vol. 23, No. 16, pp. 3414-3433. 
Konopaske, R. and Werner, S. (2005), "US managers' willingness to accept a global assignment: do expatriate benefits and assignment length make a difference?", International Journal of Human Resource Management, Vol. 16, No. 7, pp. 1159-1175.

Konopaske, R., Robie, C. and Ivancevich, J.M. (2009), "Managerial willingness to assume traveling, short-term and long-term global assignments", Management International Review, Vol. 49, pp. 359-388.

Lowe, K.B., Downes, M. and Kroeck, K.G. (1999), "The impact of gender and location on the willingness to accept overseas assignments", International Journal of Human Resource Management, Vol. 10, No. 2, pp. 223-234.

Lee, L.Y. and Sukoco, B.M. (2010), "The effects of cultural intelligence on expatriate performance: the moderating effects of international experience", International Journal of Human Resource Management, Vol. 21, No. 7, pp. 963-981.

Martin, B.A. (1989), "Gender differences in salary expectations when current salary information is provided", Psychology of Women Quarterly, Vol. 13, pp. 87-96.

McNulty, Y. \& Vance, C. (2017). "Dynamic global careers: a new conceptualization of expatriate career paths". Personnel Review, Vol. 46, No 2, pp. 205-221.

Moghimi, D. Zacher, H., Scheibe, S. and Van Yperen, N. (2017), "The selection, optimization, and compensation model in the work context: A systematic review and meta-analysis of two decades of research", Journal of Organizational Behavior, Vol.38, pp. 247-275

Noe, R.A. and Barber, A.E. (1993), "Willingness to Accept Mobility Opportunities: Destination Makes a Difference", Journal of Organizational Behavior, Vol. 14, pp. 159-175.

Oberholster, A.J., Clarke, R., Bendixen, M. and Dastoor, B. (2013), "Expatriate motivation in religious and humanitarian non-profit-organizations", Journal of Global Mobility, Vol. 1, No. 1, pp. 7-27.

Oltra, V., Bonache, J. and Brewster, C. (2013), "A new framework for understanding inequalities between expatriates and host country nationals", Journal of Business Ethics, Vol. 115, No. 2, pp. 291-310.

Pinto, L.H., Cabral-Cardoso, C. and Werther W.B. (2012), "Compelled to go abroad? Motives and outcomes of international assignments", International Journal of Human Resource Management, Vol. 23, No. 11, pp. 2295-2314.

Pinto, L.H., Cabral-Cardoso, C. and Werther W.B. (2017), "Expatriates' withdrawal intentions. The influence of organizational culture and satisfaction with the assignment", Personnel Review, Vol. 46, No. 8, pp. 1852-1869.

Roth, K. and Diamantopoulos, A. (2009), "Advancing the country image construct", Journal of Business Research, Vol. 62, pp. 726-740. 
Sanchez-Vidal, M. E., Sanz Valle, R., \& Barba Aragón, M. I. (2008). "International workers' satisfaction with the repatriation process". International Journal of Human Resource Management, Vol. 19, No. 9, pp.1683-1702.

Schweitzer, L., Lyons, S., Kuron, L. K., \& Ng, E. S. (2014). "The gender gap in pre-career salary expectations: a test of five explanations". Career Development International, 19(4), 404-425.

Schalock, R.L., Verdugo, M.A., Jenaro, C., Wang, M., Whemeyer, M., Jiancheng, X. and Lachapelle, Y. (2005), "Cross-cultural study of quality of life indicators", American Journal of Mental Retardation, Vol. 110, No. 4, pp. 298-311.

Selmer J. (2006), "Language ability and adjustment: western expatriates in China", Thunderbird International Business Review, Vol. 48, No. 3, pp. 347-368.

Selmer, J. and Lauring, J. (2011), “Acquired demographics and reasons to relocate among selfinitiated expatriates", International Journal of Human Resource Management, Vol. 22, No. 10, pp. 2055-2070.

Shah, A., \& Monahan, M. (2018). "Salary expectations and salary realities: an analysis of university students in Spain and Singapore". Journal of Organizational Psychology, 18(1), 100-115.

Shim, I.J. and Paprock, K.E. (2002), “A study focusing on American expatriates' learning in host countries", International Journal of Training and Development, Vol. 6, No. 1, pp. $13-24$.

Sims, R.H. and Schraeder, M. (2005), "Expatriate compensation: an exploratory review of salient contextual factors and common practices", Career Development International, Vol. 10, No. 2, pp. 98-108.

Stahl, G.K., Miller, E.L. and Tung R.L. (2002), "Toward the boundaryless career: a closer look at the expatriate career concept and perceived implications of an international assignment”, Journal of World Business, Vol. 37, pp. 216-227.

Stoermer, S., Davies, S. E., Bahrisch, O., \& Portniagin, F. (2017). “For sensation's sake: differences in female and male expatriates' relocation willingness to dangerous countries based on sensation seeking”. Journal of Global Mobility, Vol. 5, No. 4, pp. 374-390.

Suutari, V. and Brewster, C. (2000), "Making their own way: international experience through self-initiated foreign assignments”, Journal of World Business, Vol. 35, No. 4, pp. 2000.

Suutari, V., Brewster, C., Dickmann, M., Mäkelä, L., Tanskenan, J. and Tornikoski, C. (2018). "The effect of international work experience on the career success of expatriates: a 
comparison of assigned and self-initiated expatriates". Human Resource Management. Vol. 57, No. 1, pp. 37-54

Suutari, V. and Tornikoski, C. (2001), "The challenge of expatriate compensation: the source of satisfaction and dissatisfaction among expatriates", International Journal of Human Resource Management, Vol. 12, No. 3, pp. 389-404.

Suutari, V., Tornikoski, C. and Mäkela, L. (2012), "Career decision making of global careerists", International Journal of Human Resource Management, Vol. 23, No. 16, pp. 3455-3478.

Takeuchi, R., Tesluk, P.E., Yun, S. and Lepak D.P. (2005), "An integrative view of international work experience", Academy of Management Journal, Vol. 48, No. 1, pp. 85-100.

Takeuchi, R., Yun, S. and Russell, J.E.A. (2002), "Antecedents and consequences of the perceived adjustment of Japanese Expatriates in the USA", International Journal of Human Resource Management, Vol. 13, No. 8, pp. 1224-1244.

Tarique, I. and Weisbord, E. (2013), “Antecedents of dynamic cross-cultural competence in adult third culture kids (ATCKs)", Journal of Global Mobility, Vol. 1, No. 4, pp. 139160.

Tharenou, P. (2008), "Disruptive decisions to leave home: gender and family differences in expatriation choices", Organizational Behavior and Human Decision Processes, Vol. 105, pp. 183-200.

Toh, S. M. and DeNisi, A. S. (2003), "Host country nationals reaction to expatriate pay policies: a model and implications", Academy of Management Review, Vol. 28, No. 4, pp. 606621.

Toh, S. M. and DeNisi, A. S. (2007), "Host country nationals as socializing agents: a social identity approach", Journal of Organizational Behaviour, Vol. 28, pp. 281-301.

Tornikoski, C. (2011). "Fostering expatriates affective commitment: a total reward perspective". Cross Cultural Management: An International Journal, Vol. 18, No. 2, pp. 214-235.

UNESCO, (2010), "Engineering: Issues, Challenges and Opportunities for Development", Paris, UNESCO Publishing.

von Bonsdorff, M.E. (2011), “Age-related differences in reward preferences”, International Journal of Human Resource Management, Vol. 22, No. 6, pp. 1262-1276.

van der Velde, M.E.G., Bossink, C.J.H. and Jansen, P.G.W. (2005), "Gender differences in the determinants of the willingness to accept an international assignment", Journal of Vocational Behavior, Vol. 66, pp. 81-103. 
Wagner, M.R. and Westaby, J.D. (2009), "The willingness to relocate to another country: the impact of cultural similarity, destination safety, and financial incentive", International Journal of Psychology, Vol. 44, No. 4, pp. 257-265.

Warneke, D. and Scheneider, M. (2011), "Expatriate compensation packages: what do employees prefer?", Cross Cultural Management: An International Journal, Vol. 18, No. 2, pp. 236-256. 
Table 1. Yearly net salary expectations to Job Offers

\begin{tabular}{|c|c|c|c|c|c|c|c|c|c|}
\hline & \multicolumn{4}{|c|}{$\begin{array}{c}\text { Yearly net salary expectation } \\
\text { Job offer A (euros) }\end{array}$} & \multicolumn{4}{|c|}{$\begin{array}{c}\text { Yearly net salary expectation } \\
\text { Job offer B (euros) }\end{array}$} & \multirow{2}{*}{$\begin{array}{c}\text { Dif } \\
\text { Job B/ } \\
\text { Job A *3 }\end{array}$} \\
\hline & $\mathrm{N}$ & Mean & SD & $\begin{array}{l}\text { Dif Home } \\
\text { Country*1 }\end{array}$ & $\mathrm{N}$ & Mean & SD & $\begin{array}{l}\text { Dif Home } \\
\text { Country*2 }\end{array}$ & \\
\hline Home Country & 470 & 71,453 & 72,847 & & 470 & 93,472 & 91,288 & & \\
\hline Algeria & 449 & 93,952 & 70,466 & $57.2 \%$ & 443 & 129,478 & 104,830 & $55.3 \%$ & $43.4 \%$ \\
\hline Angola & 455 & 98,827 & 77,714 & $66.2 \%$ & 451 & 134,047 & 112,253 & 62.8 & $45.0 \%$ \\
\hline Argentina & 469 & 80,696 & 59,585 & $35.4 \%$ & 463 & 112,462 & 87,412 & $36.1 \%$ & $44.6 \%$ \\
\hline Chile & 470 & 79,944 & 59,143 & $35.7 \%$ & 462 & 111,121 & 85,896 & $35.1 \%$ & $44.6 \%$ \\
\hline Dem. R. Congo & 436 & 106,024 & 82,550 & $78.0 \%$ & 432 & 144,355 & 122,511 & $73.3 \%$ & $42.7 \%$ \\
\hline Mozambique & 462 & 96,343 & 73,613 & $64.9 \%$ & 453 & 131,346 & 113,377 & $59.4 \%$ & $40.1 \%$ \\
\hline
\end{tabular}

\section{Note:}

Job Offer A - Lead Engineer; Job Offer B - Project Manager

*1 Differential Job A = Average of individual observations (salary expectation for job offer A on hostcountry - salary expectation for job offer A on home-country)/ salary expectation for job offer A on home-country x 100

*2 Differential Job B = Average of individual observations (salary expectation for job offer B on hostcountry - salary expectation for job offer B on home-country)/ salary expectation for job offer B on home-country x 100

*3 Differential Job B / Job A = Average of individual observations (salary expectation for job offer B on host-country - salary expectation for job offer A on host-country)/ salary expectation for job offer A on host-country x 100 
Table 2. Hierarchical regression analysis of salary expectations to Job offer A - Lead Engineer

\begin{tabular}{|c|c|c|c|c|c|c|c|c|c|c|c|c|c|}
\hline \multirow[b]{2}{*}{ Models } & \multirow{2}{*}{\begin{tabular}{|c|} 
Home Country \\
1
\end{tabular}} & \multicolumn{2}{|c|}{ Algeria } & \multicolumn{2}{|c|}{ Angola } & \multicolumn{2}{|c|}{ Argentina } & \multicolumn{2}{|c|}{ Chile } & \multicolumn{2}{|c|}{ Dem. Republic Congo } & \multicolumn{2}{|c|}{ Mozambique. } \\
\hline & & 2 & 3 & 4 & 5 & 6 & 7 & 8 & 9 & 10 & 11 & 12 & 13 \\
\hline Intersection & -7.765 & 33.787 & 93.655 & -8.498 & 37.790 & -3.913 & 44.351 & 15.525 & 47.195 & 2333 & 49.247 & -3.158 & 20.834 \\
\hline Age & $.20 * *$ & $.18^{* *}$ & $.19^{* *}$ & $.23^{* *}$ & $.25^{* *}$ & $.25^{* *}$ & $.26^{* *}$ & $.21 * *$ & $.22^{* *}$ & $.23 * *$ & $.23^{* *}$ & $.26^{* *}$ & $30^{*}$ \\
\hline Male (dummy) & $-.02 \mathrm{~ns}$ & $-.02 \mathrm{~ns}$ & $-.01 \mathrm{~ns}$ & $.01 \mathrm{~ns}$ & $-.01 \mathrm{~ns}$ & $.01 \mathrm{~ns}$ & $.00 \mathrm{~ns}$ & $.03 \mathrm{~ns}$ & $.02 \mathrm{~ns}$ & $-.03 \mathrm{~ns}$ & $-.01 \mathrm{~ns}$ & $.02 \mathrm{~ns}$ & $.03 \mathrm{~ns}$ \\
\hline Not single (dummy) & $.01 \mathrm{~ns}$ & $.13^{*}$ & $.13^{*}$ & $.10 \mathrm{~ns}$ &, $12 *$ & $.13^{*}$ & $.11 \mathrm{~ns}$ & $.14^{*}$ & $.11 \mathrm{~ns}$ & $.12 *$ & $.13 *$ &, $12 *$ &, $11 \mathrm{~ns}$ \\
\hline $\mathrm{N}^{\circ}$ Child $<13$ y ears & $\mathrm{ns}$ & $.01 \mathrm{~ns}$ & $.01 \mathrm{~ns}$ & $-.03 \mathrm{~ns}$ & $-.03 \mathrm{~ns}$ & $-.05 \mathrm{~ns}$ & $-.04 \mathrm{~ns}$ & $-.04 \mathrm{~ns}$ & $-.02 \mathrm{~ns}$ & $-.05 \mathrm{~ns}$ & $-.05 \mathrm{~ns}$ & $-.04 \mathrm{~ns}$ & $-.06 \mathrm{~ns}$ \\
\hline Full contract (dummy) & $.15^{* *}$ & .13 * & $.15^{* *}$ & $.10 \mathrm{~ns}$ & $.09 \mathrm{~ns}$ & $.09 \mathrm{~ns}$ & $.08 \mathrm{~ns}$ & $.06 \mathrm{~ns}$ & $.07 \mathrm{~ns}$ & $.14^{* *}$ & $.15^{* *}$ & $.10 \mathrm{~ns}$ & $.10 \mathrm{~ns}$ \\
\hline Seniority & $.08^{* *}$ & $.08 \mathrm{~ns}$ & $.08 \mathrm{~ns}$ & $.11^{*}$ &, $11^{*}$ & $.09 \mathrm{~ns}$ & $.08 \mathrm{~ns}$ & $.10^{*}$ & $.10 *$ & $.14^{* *}$ & $.14^{* *}$ & $.14^{* *}$ & $.14^{* *}$ \\
\hline Previous Intern. Exp. & $-.06 * *$ & $-.08 \mathrm{~ns}$ & $-.06 \mathrm{~ns}$ & $-.10^{*}$ & $-.07 \mathrm{~ns}$ & $-.08 \mathrm{~ns}$ & $-.05 \mathrm{~ns}$ & $-.08 \mathrm{~ns}$ & $-.06 \mathrm{~ns}$ & $-.09 \mathrm{~ns}$ & $-.09 \mathrm{~ns}$ & $-.11^{*}$ & $-.09 \mathrm{~ns}$ \\
\hline Nat Country Language & & $-.07 \mathrm{~ns}$ & $-.01 \mathrm{~ns}$ & $-.08 \mathrm{~ns}$ & $-.05 \mathrm{~ns}$ & $-.01 \mathrm{~ns}$ & $-.03 \mathrm{~ns}$ & $-.02 \mathrm{~ns}$ & $-.01 \mathrm{~ns}$ & $-.02 \mathrm{~ns}$ & $.02 \mathrm{~ns}$ & $-.11 *$ & $-.06 \mathrm{~ns}$ \\
\hline $\begin{array}{l}\text { Motives - Current } \\
\text { Situation }\end{array}$ & & $-.15^{* *}$ & $-.16^{* *}$ & $-.12 *$ & $-.12 *$ & $-.10^{*}$ & $-.10^{*}$ & $-.13^{* *}$ & $-.13^{* *}$ & $-.09 \mathrm{~ns}$ &,$- 10^{*}$ &,$- 09 *$ &,$- 08 \mathrm{~ns}$ \\
\hline Motives - Family & & $.00 \mathrm{~ns}$ & $-.02 \mathrm{~ns}$ & $.01 \mathrm{~ns}$ & $.01 \mathrm{~ns}$ & $.00 \mathrm{~ns}$ & $.01 \mathrm{~ns}$ & $-.02 \mathrm{~ns}$ & $.00 \mathrm{~ns}$ & $-.01 \mathrm{~ns}$ & $-.03 \mathrm{~ns}$ & $.01 \mathrm{~ns}$ & $.01 \mathrm{~ns}$ \\
\hline $\begin{array}{l}\text { Motives - Personal } \\
\text { Challenge }\end{array}$ & & $.02 \mathrm{~ns}$ & $.05 \mathrm{~ns}$ & $.04 \mathrm{~ns}$ & $.04 \mathrm{~ns}$ & $.03 \mathrm{~ns}$ & $.06 \mathrm{~ns}$ & $.02 \mathrm{~ns}$ & $.05 \mathrm{~ns}$ & $.02 \mathrm{~ns}$ & $.04 \mathrm{~ns}$ & $.00 \mathrm{~ns}$ & $.02 \mathrm{~ns}$ \\
\hline $\begin{array}{l}\text { Motives - Professional } \\
\text { Opportunity }\end{array}$ & & $-.04 \mathrm{~ns}$ & $-.02 \mathrm{~ns}$ & $.01 \mathrm{~ns}$ & $.01 \mathrm{~ns}$ & $.02 \mathrm{~ns}$ & $.01 \mathrm{~ns}$ & $-.01 \mathrm{~ns}$ & $-.01 \mathrm{~ns}$ & $-.01 \mathrm{~ns}$ & $-.02 \mathrm{~ns}$ & $.02 \mathrm{~ns}$ & $.01 \mathrm{~ns}$ \\
\hline Motives - Fin an cial & & $.09 \mathrm{~ns}$ & $.07 \mathrm{~ns}$ & $.07 \mathrm{~ns}$ & $.07 \mathrm{~ns}$ & $.04 \mathrm{~ns}$ & $.03 \mathrm{~ns}$ & $.08 \mathrm{~ns}$ & $.05 \mathrm{~ns}$ & $.05 \mathrm{~ns}$ & $.03 \mathrm{~ns}$ & $.05 \mathrm{~ns}$ & $.04 \mathrm{~ns}$ \\
\hline Safety & & & $-.05 n s$ & & $-.08 \mathrm{~ns}$ & & $.00 \mathrm{~ns}$ & & $-.04 \mathrm{~ns}$ & & $-.12 \mathrm{~ns}$ & & $-.11 \mathrm{~ns}$ \\
\hline Healthcare & & & $-.05 \mathrm{~ns}$ & & $.01 \mathrm{~ns}$ & & $-.02 \mathrm{~ns}$ & & $-.01 \mathrm{~ns}$ & & $-.03 \mathrm{~ns}$ & & $.03 \mathrm{~ns}$ \\
\hline Infrastructures & & & $-.03 \mathrm{~ns}$ & &,$- 12^{*}$ & & $-.07 \mathrm{~ns}$ & & $-.03 \mathrm{~ns}$ & & $-.08 \mathrm{~ns}$ & & $-.18^{* *}$ \\
\hline Political Stability & & & $-.07 \mathrm{~ns}$ & & $.02 \mathrm{~ns}$ & & $.00 \mathrm{~ns}$ & & $-.01 \mathrm{~ns}$ & & $.08 \mathrm{~ns}$ & & $.07 \mathrm{~ns}$ \\
\hline Openness & & & $-.07 \mathrm{~ns}$ & & $-.04 \mathrm{~ns}$ & & $.05 \mathrm{~ns}$ & & $.01 \mathrm{~ns}$ & & $-.04 \mathrm{~ns}$ & & $.02 \mathrm{~ns}$ \\
\hline Culture Attraction & & & $-.14 * *$ & & $-.07 \mathrm{~ns}$ & & $-.17^{* *}$ & & $-.18^{* *}$ & & $-.02 \mathrm{~ns}$ & & $-.12^{*}$ \\
\hline Age $\mathrm{x}$ Infrastructures & & & $.06 \mathrm{~ns}$ & & $-.05 \mathrm{~ns}$ & & $-.11^{*}$ & & ns & & $.00 \mathrm{~ns}$ & & $-.08 \mathrm{~ns}$ \\
\hline Age $x$ Cult Attraction & & & $-.10^{*}$ & & $-.10^{*}$ & & $.00 \mathrm{~ns}$ & & $\mathrm{~ns}$ & & $.02 \mathrm{~ns}$ & & $-.13 * *$ \\
\hline$\Delta \mathrm{R}^{2}$ & & & 0,06 & & 0,03 & & 0,03 & & 0,02 & & 0,01 & & 0,05 \\
\hline F Change & $33.05 * *$ & $5.80 * *$ & $4.87 * *$ & $4.88 * *$ & $2.42 *$ & $5.10 * *$ & $2.75^{*}$ & $4.83 * *$ & $1.92 *$ & $5.58 * *$ & $1.84 \mathrm{~ns}$ & $5.71 * *$ & $4.06 * *$ \\
\hline Adjusted $\mathrm{R}^{2}$ & 0,08 & 0,14 & 0,20 & 0,11 & 0,14 & 0,11 & 0,14 & 0,11 & 0,13 & 0,14 & 0,15 & 0,13 & 0,18 \\
\hline
\end{tabular}

Standardized $\beta$ with t-test significance $* * p<.01, * p<.05, \mathrm{~ns}=$ ' not significant' 
Table 3. Hierarchical regression analysis of salary expectations to Job offer B - Project Manager

\begin{tabular}{|c|c|c|c|c|c|c|c|c|c|c|c|c|c|}
\hline \multirow[b]{2}{*}{ Models } & \multirow{2}{*}{\begin{tabular}{|c|} 
Home Country \\
14 \\
\end{tabular}} & \multicolumn{2}{|c|}{ Algeria } & \multicolumn{2}{|c|}{ Angola } & \multicolumn{2}{|c|}{ Argentina } & \multicolumn{2}{|c|}{ Chile } & \multicolumn{2}{|c|}{ Dem. Republic Congo } & \multicolumn{2}{|c|}{ Mozambique. } \\
\hline & & 15 & 16 & 17 & 18 & 19 & 20 & 21 & 22 & 23 & 24 & 25 & 26 \\
\hline Intersection & 43.843 & 12.435 & 69.892 & -12.972 & 29.777 & 15.937 & 69.929 & 45.154 & 82.279 & 5.962 & 42.568 & -3.137 & 24.446 \\
\hline Age & $.12 *$ & $.19 * *$ & $.20 * *$ & $.17 * *$ & $.18 * *$ & $.19 * *$ & $.19 * *$ & $.17 * *$ & $.17^{* *}$ & $.17^{* *}$ & $.18 * *$ & $.19 * *$ & $.24 * *$ \\
\hline Male (dummy) & $-.03 \mathrm{~ns}$ & $-.01 \mathrm{~ns}$ & $-.03 \mathrm{~ns}$ & $.03 \mathrm{~ns}$ & $.02 \mathrm{~ns}$ & $.03 \mathrm{~ns}$ & $.03 \mathrm{~ns}$ & $.05 \mathrm{~ns}$ & $.04 \mathrm{~ns}$ & $-.03 \mathrm{~ns}$ & $-.01 \mathrm{~ns}$ & $.02 \mathrm{~ns}$ & $.03 \mathrm{~ns}$ \\
\hline Not single (dummy) & $.12 * *$ & $.11 \mathrm{~ns}$ & $.11 \mathrm{~ns}$ & $.07 \mathrm{~ns}$ & $.08 \mathrm{~ns}$ & $.11 \mathrm{~ns}$ & $.11 \mathrm{~ns}$ & $.10 \mathrm{~ns}$ & $.09 \mathrm{~ns}$ & $.08 \mathrm{~ns}$ & $.08 \mathrm{~ns}$ & $.07 \mathrm{~ns}$ & $.05 \mathrm{~ns}$ \\
\hline $\mathrm{N}^{\circ}$ Child $<13$ years & $-.03 \mathrm{~ns}$ & $-.08 \mathrm{~ns}$ & $-.09 \mathrm{~ns}$ & $-.07 \mathrm{~ns}$ & $-.09 \mathrm{~ns}$ & $-.09 \mathrm{~ns}$ & $-.10 \mathrm{~ns}$ & $-.07 \mathrm{~ns}$ & $-.07 \mathrm{~ns}$ & $-.12 *$ & $-.11 \mathrm{~ns}$ & $-.10 \mathrm{~ns}$ & $-.10 \mathrm{~ns}$ \\
\hline Full contract (dummy) & $.05 *$ & $.11 *$ & $.12 *$ & $.10 \mathrm{~ns}$ & $.09 \mathrm{~ns}$ & $.07 \mathrm{~ns}$ & $.05 \mathrm{~ns}$ & $.03 \mathrm{~ns}$ & $.05 \mathrm{~ns}$ & $.14^{* *}$ & $.13 \mathrm{~ns}$ & $.09 \mathrm{~ns}$ & $.09 \mathrm{~ns}$ \\
\hline Seniority & $.13 * *$ & $.16 * *$ & $.16 * *$ & $.18 * *$ & $.18 * *$ & $.18^{* *}$ & $.17 * *$ & $.20 * *$ & $.18^{* *}$ & $.18^{* *}$ & $.19 * *$ & $.15^{* *}$ & $.15^{* *}$ \\
\hline Previous Intern. Exp. & $.05 \mathrm{~ns}$ & $-.12 *$ & $-.09 \mathrm{~ns}$ & $-.15 * *$ & $-.12 *$ & $-.14 * *$ & $-.11 *$ & $-.13 * *$ & $-.11 *$ & $-.10 *$ & $-.10 *$ & $-.15 * *$ & $-.13 * *$ \\
\hline Nat Country Language & & $.04 \mathrm{~ns}$ & $.00 \mathrm{~ns}$ & $-.08 \mathrm{~ns}$ & $-.07 \mathrm{~ns}$ & $.02 \mathrm{~ns}$ & $.00 \mathrm{~ns}$ & $-.01 \mathrm{~ns}$ & $-.01 \mathrm{~ns}$ & $-.03 \mathrm{~ns}$ & $.01 \mathrm{~ns}$ & $-.11 *$ & $-.06 \mathrm{~ns}$ \\
\hline $\begin{array}{l}\text { Motives - Current } \\
\text { Situation }\end{array}$ & & $-.11 *$ & $-.11 *$ & $-.08 \mathrm{~ns}$ & $-.09 \mathrm{~ns}$ &,$- 10 *$ &,$- \mathbf{1 0} *$ &,$- 1^{*}$ &,$- 1^{*}$ & $-.08 \mathrm{~ns}$ & $-.09 *$ & $-.08 \mathrm{~ns}$ & $-.08 \mathrm{~ns}$ \\
\hline Motives - Family & & $.01 \mathrm{~ns}$ & $.01 \mathrm{~ns}$ & $.07 \mathrm{~ns}$ & $.05 \mathrm{~ns}$ & $.02 \mathrm{~ns}$ & $.02 \mathrm{~ns}$ & $.00 \mathrm{~ns}$ & $.01 \mathrm{~ns}$ & $.03 \mathrm{~ns}$ & $.01 \mathrm{~ns}$ & $.06 \mathrm{~ns}$ & $.05 \mathrm{~ns}$ \\
\hline $\begin{array}{l}\text { Motives - Personal } \\
\text { Challenge }\end{array}$ & & $-.02 \mathrm{~ns}$ & $-.02 \mathrm{~ns}$ & $.01 \mathrm{~ns}$ & $.01 \mathrm{~ns}$ & $-.02 \mathrm{~ns}$ & $.00 \mathrm{~ns}$ & $-.06 \mathrm{~ns}$ & $-.05 \mathrm{~ns}$ & $.00 \mathrm{~ns}$ & $.03 \mathrm{~ns}$ & $-.02 \mathrm{~ns}$ & $-.01 \mathrm{~ns}$ \\
\hline $\begin{array}{l}\text { Motives - Professional } \\
\text { Opportunity }\end{array}$ & & $.04 \mathrm{~ns}$ & $.04 \mathrm{~ns}$ & $.02 \mathrm{~ns}$ & $.02 \mathrm{~ns}$ & $.04 \mathrm{~ns}$ & $.04 \mathrm{~ns}$ & $.05 \mathrm{~ns}$ & $.05 \mathrm{~ns}$ & $.02 \mathrm{~ns}$ & $.03 \mathrm{~ns}$ & $.04 \mathrm{~ns}$ & $.06 \mathrm{~ns}$ \\
\hline Motives - Financial & & $.07 \mathrm{~ns}$ & $.07 \mathrm{~ns}$ & $.07 \mathrm{~ns}$ & $.07 \mathrm{~ns}$ & $.04 \mathrm{~ns}$ & $.04 \mathrm{~ns}$ & $.05 \mathrm{~ns}$ & $.04 \mathrm{~ns}$ & $.03 \mathrm{~ns}$ & $.02 \mathrm{~ns}$ & $.05 \mathrm{~ns}$ & $.04 \mathrm{~ns}$ \\
\hline Safety & & & $.00 \mathrm{~ns}$ & & $.08 \mathrm{~ns}$ & & $.07 \mathrm{~ns}$ & & $.02 \mathrm{~ns}$ & & $-.08 \mathrm{~ns}$ & & $-.08 \mathrm{~ns}$ \\
\hline Healthcare & & & $.01 \mathrm{~ns}$ & & $.06 \mathrm{~ns}$ & & $.06 \mathrm{~ns}$ & & $.02 \mathrm{~ns}$ & & $.00 \mathrm{~ns}$ & & $.04 \mathrm{~ns}$ \\
\hline Infrastructures & & & $-.14 *$ & & $-.24 * *$ & & $-.15 * *$ & & $-.06 \mathrm{~ns}$ & & $-.17 * *$ & & -.21 ** \\
\hline Political Stability & & & $-.02 \mathrm{~ns}$ & & $-.02 \mathrm{~ns}$ & & $.00 \mathrm{~ns}$ & & $.00 \mathrm{~ns}$ & & $.06 \mathrm{~ns}$ & & $.04 \mathrm{~ns}$ \\
\hline Openness & & & $-.07 \mathrm{~ns}$ & & $-.02 \mathrm{~ns}$ & & $-.03 \mathrm{~ns}$ & & $.00 \mathrm{~ns}$ & & $-.02 \mathrm{~ns}$ & & $.03 \mathrm{~ns}$ \\
\hline Culture Attraction & & & $-.14 * *$ & & $-.09 \mathrm{~ns}$ & & $-.08 \mathrm{~ns}$ & & $-.11 \mathrm{~ns}$ & & $-.05 \mathrm{~ns}$ & & $-.12 *$ \\
\hline Age $x$ Infrastructures & & & $.03 \mathrm{~ns}$ & & $-.04 \mathrm{~ns}$ & & $-.13 * *$ & & $-.06 \mathrm{~ns}$ & & $-.01 \mathrm{~ns}$ & & $.06 \mathrm{~ns}$ \\
\hline Age $\mathrm{x}$ Cult Attraction & & & $-.14 * *$ & & $-.10 *$ & & $.03 \mathrm{~ns}$ & & $.02 \mathrm{~ns}$ & & $-.01 \mathrm{~ns}$ & &.$- .14 *$ \\
\hline$\Delta \mathrm{R}^{2}$ & & & 0,05 & & 0,04 & & 0,01 & & $-0,01$ & & 0,02 & & 0,05 \\
\hline F Change & $21.47 * *$ & $4.97 * *$ & $3.56 * *$ & $4.40 * *$ & $3.43 * *$ & $4.50 * *$ & $2.25 *$ & $4.19 * *$ & $.90 \mathrm{~ns}$ & $4.20 * *$ & $1.90 \mathrm{~ns}$ & $4.12 * *$ & $3.67^{* *}$ \\
\hline Adjusted $\mathrm{R}^{2}$ & 0,05 & 0,12 & 0,17 & 0,10 & 0,14 & 0,10 & 0,11 & 0,10 & 0,09 & 0,10 & 0,12 & 0,09 & 0,14 \\
\hline
\end{tabular}

Standardized $\beta$ with t-test significance $* * p<.01, * p<.05$, ns $=$ 'not significant' 


\section{Figure 1}

\section{Antecedents of Salary Expectations}

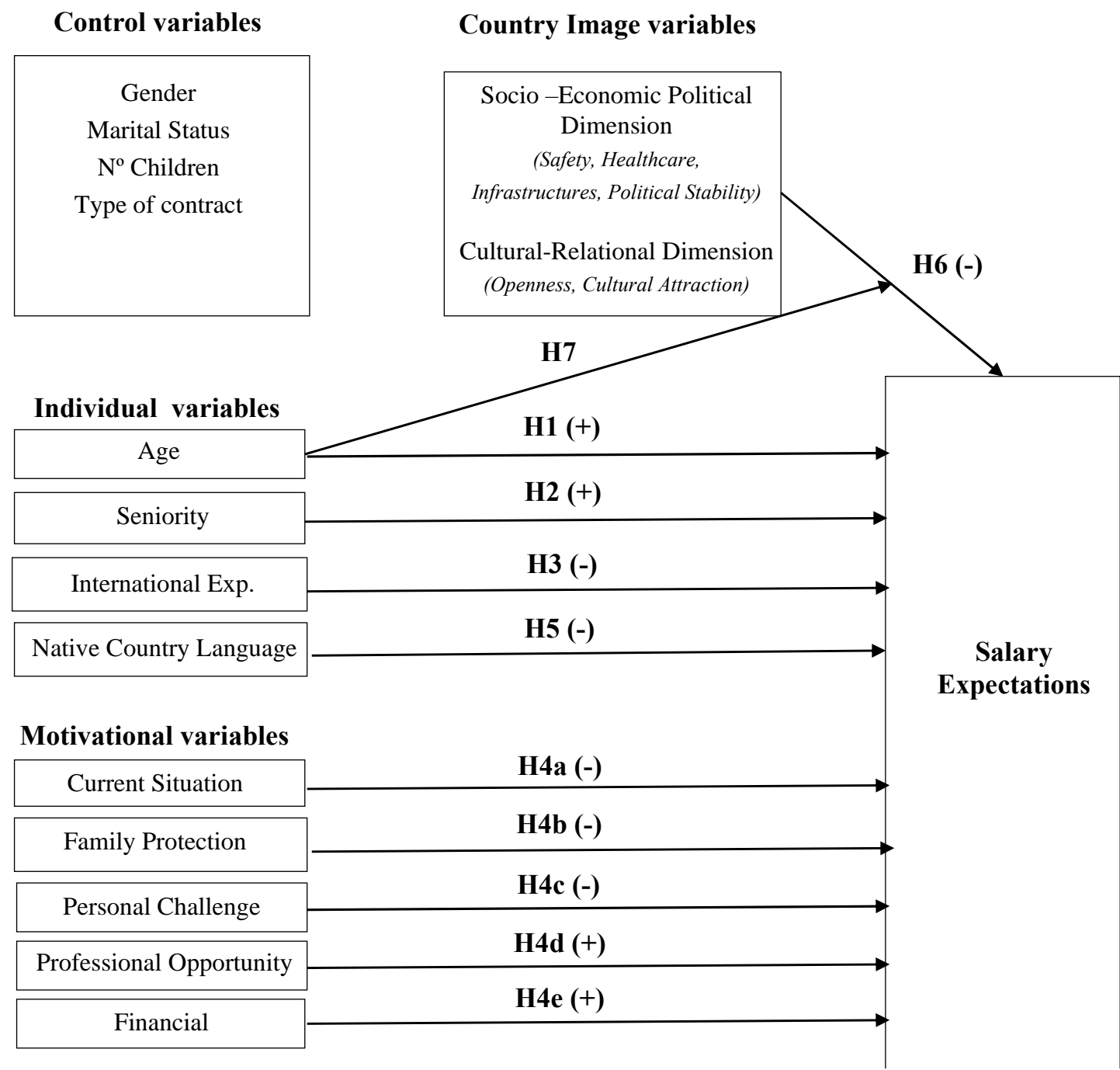




\section{Figure 2}

Moderation relativity Job Offer A - Lead Engineer
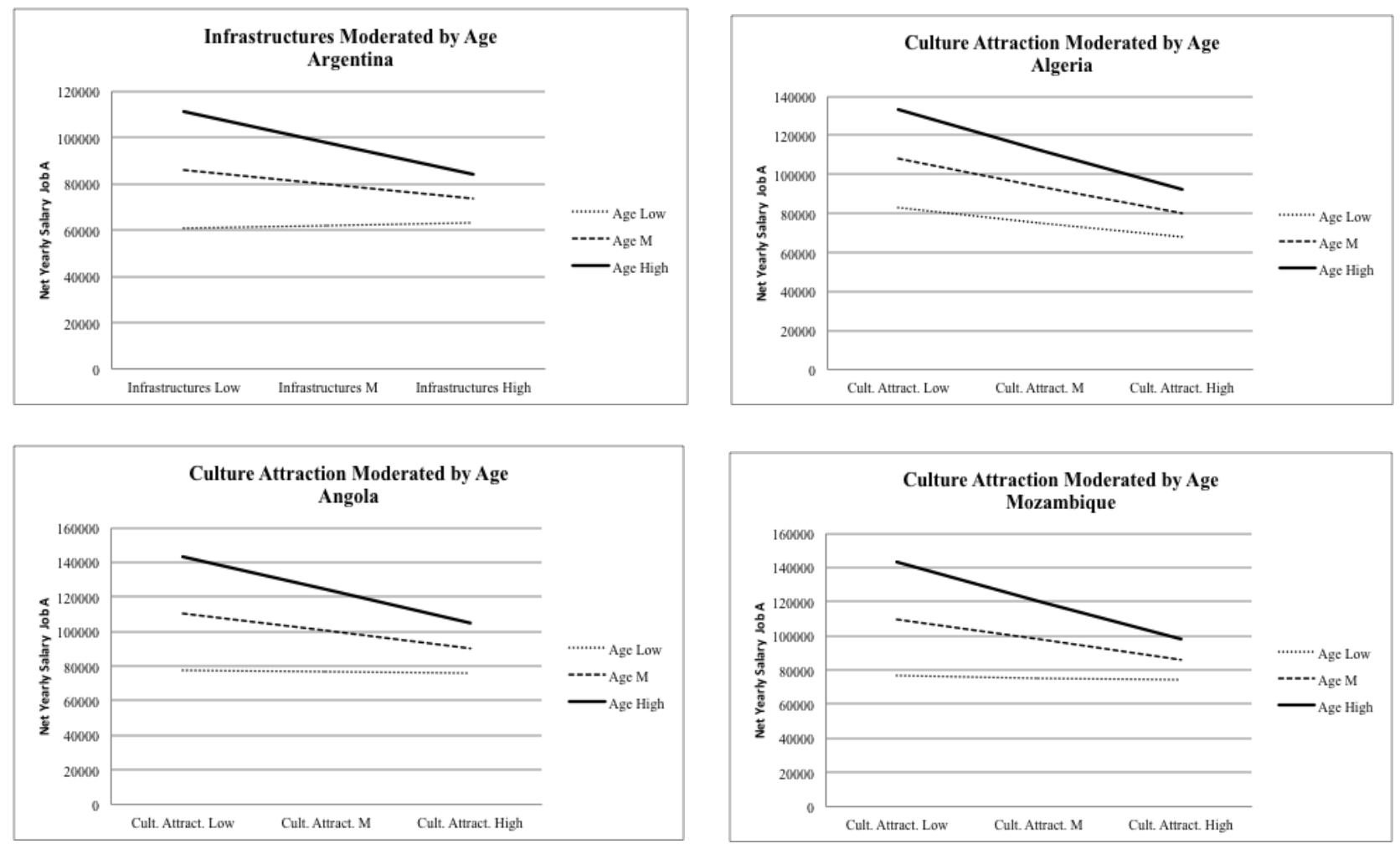

Moderations relativity Job Offer B - Project Manager
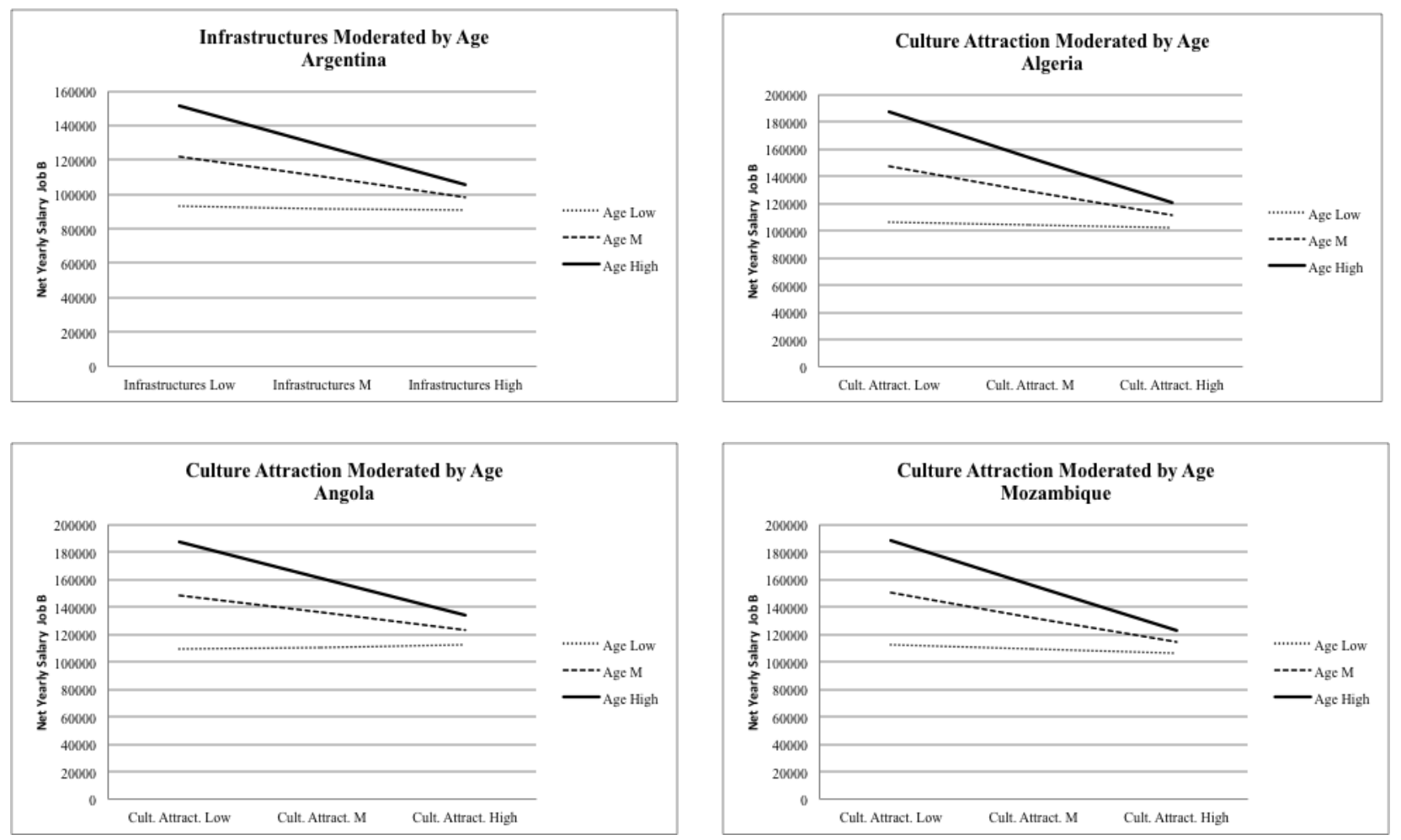